\title{
Intraperitoneal dedifferentiated liposarcoma: A case report
}

\author{
Ali Karaman, Mehmet Eşref Kabalar, Önder Özcan, Timur Koca, Doğan Nasır Binici
}

Ali Karaman, Department of Medical Genetics, State Hospital, Erzurum 25240, Turkey

Mehmet Eşref Kabalar, Department of Pathology, State Hospital, Erzurum 25240, Turkey

Önder Özcan, Department of General Surgery, State Hospital, Erzurum 25240, Turkey

Timur Koca, Department of Radiation Oncology, State Hospital, Erzurum 25240, Turkey

Doğan Nasır Binici, Department of Internal Medicine, State Hospital, Erzurum 25240, Turkey

Author contributions: Karaman A performed the PCR analysis of adipose tumor samples and wrote the article; Kabalar ME analyzed the biopsy material; Binici DN performed the physical examination; Özcan Ö performed the surgical operation; Koca T performed the radiation therapy.

Correspondence to: Ali Karaman, MD, Erzurum State Hospital, (Erzurum Numune Hastanesi), Department of Medical Genetics, Erzurum 25240, Turkey. alikaramandr@hotmail.com Telephone: +90-442-2321139 Fax: +90-442-2321390

Received: June 30, 2008

Accepted: September 3, 2008

Published online: October 14, 2008 from: URL: http://www.wjgnet.com/1007-9327/14/5927.asp DOI: http://dx.doi.org/10.3748/wjg.14.5927

\section{INTRODUCTION}

Liposarcoma is one of the most frequent malignant soft tissue tumors and currently classified into five main subgroups: well-differentiated, myxoid, round cell, pleomorphic, and dedifferentiated ${ }^{[1]}$. It is generally accepted that $p 53$ mutations in human malignant tumors are often related to a poor prognosis ${ }^{[2,3]}$. Taubert $e a^{l^{4]}}$ reported that patients with nonframeshift mutations have a rather poor prognosis. Moreover, p53 overexpression alone is associated with a poor clinical outcome ${ }^{[5,6]}$. Mutations of the $p 53$ gene have been found in different types of soft tissue sarcoma ${ }^{[7]}$. Welldifferentiated liposarcoma is the most common variant. Dedifferentiated liposarcoma, a variant of liposarcoma with a worse prognosis, has a less frequency and occurs most commonly in retroperitoneum ${ }^{[8,9]}$.

\section{CASE REPORT}

A 62-year-old man presented with a 3-mo history of constant right flank discomfort, fatigue, recent weight loss, loss of appetite and abdominal fullness. Physical examination revealed an abdominal mass in the right lower quadrant. T1-weighted magnetic resonance image (MRI) of the abdomen demonstrated a high-intensity mass. The tumor, located at intraperitoneum, was in the inferio-lateral to the cecum (Figure 1). Laboratory tests including tumor markers showed no abnormality. Surgery was performed to expose the tumor through a right lower abdominal incision. Gross examination revealed a $10 \mathrm{~cm}$ yellow, fleshy mass. Pathological examination revealed a dedifferentiated liposarcoma (Figure 2). Immunolabeling for S-100 was positive, while CD117 (C-KIT) and CD34 were negative in the welldifferentiated tumor tissue samples, thus ruling out a gastrointestinal stromal tumor. Based on the histology and immunoprofile, a diagnosis of dedifferentiated liposarcoma was established. Furthermore, we investigated the occurrence of $p 53$ gene mutations in the tumor samples.

\section{DNA extraction}

Tissue samples were incubated for $15 \mathrm{~min}$ at $65^{\circ} \mathrm{C}$, 


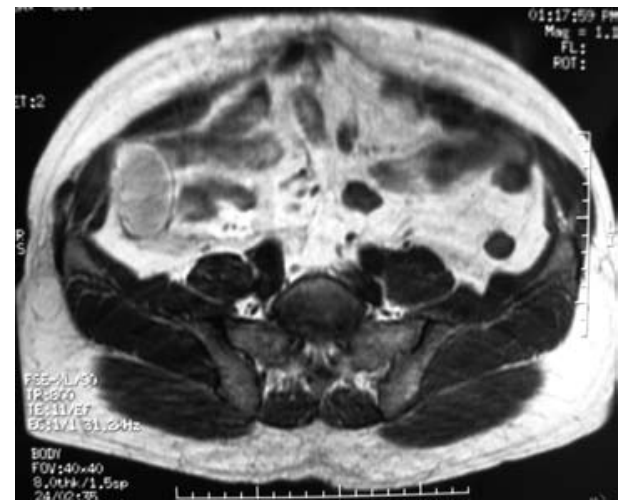

Figure 1 T1-weighted magnetic resonance image (MRI) demonstrating a highintensity mass.
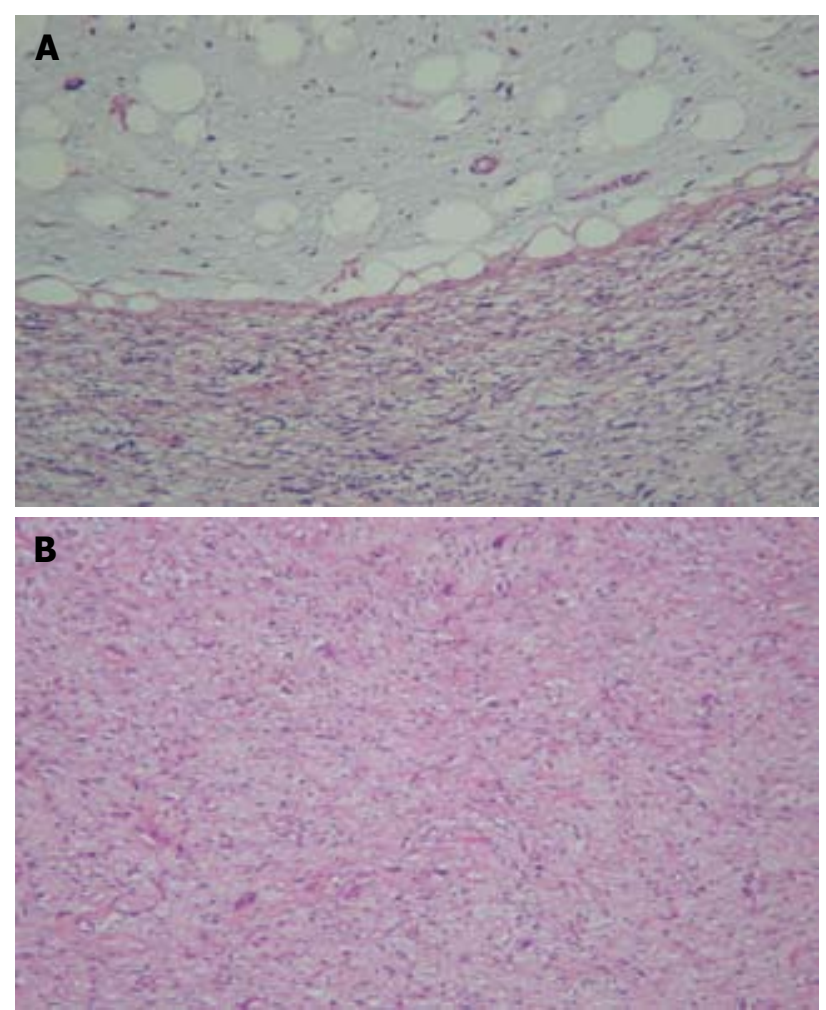

Figure 2 Well-differentiated tumor shows numerous lipoblasts and the dedifferentiated tumor resembles pleomorphic, spindle cells with hyperchromatic nuclei $(\mathrm{HE}, \times 100)$ in the area revealing an abrupt transition from the welldifferentiated to the dedifferentiated tumor (A), and dedifferentiated tumor shows low cellularity, fusiform cells with small hyperchromatic nuclei, and abundant collogen in the low grade fibrosarcoma area (B) (HE, x 100).

then overnight at $37^{\circ} \mathrm{C}$ in a lytic solution containing $1 \mathrm{mg} / \mathrm{mL}$ proteinase $\mathrm{K}, 10 \mathrm{mmol} / \mathrm{L}$ Tris $/ \mathrm{HCl}$, $10 \mathrm{mmol} / \mathrm{L}$ ethylene diamine tetraacetic acid, 150 $\mathrm{mmol} / \mathrm{L} \mathrm{NaCl}, 0.4 \%$ sodium dodecyl sulfate. DNA was extracted twice with an equal volume of 1:1 SSphenol/chloroform, and precipitated for $2 \mathrm{~h}$ at -20 ${ }^{\circ} \mathrm{C}$ after addition of 0.1 volume of $3 \mathrm{~mol} / \mathrm{L}$ sodium acetate, $20 \mu \mathrm{g}$ of glycogen as a carrier, and 2.5 volume of $100 \%$ ethanol. After centrifugation, the precipitate was washed with $2 \mathrm{~mL}$ of $80 \%$ ethanol, dried with a Speed Vac concentrator, and reconstituted with $50 \mu \mathrm{L}$ of TE buffer.

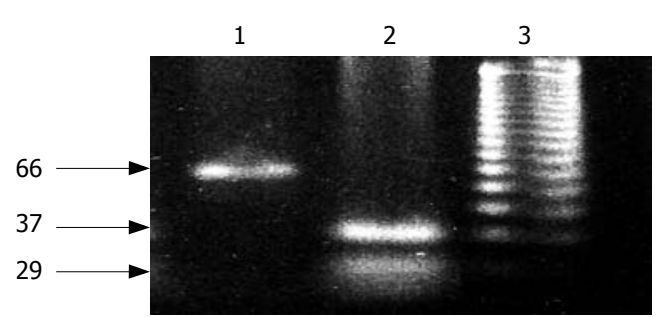

Figure 3 Amplification of the BstU1 within exon 4 produces a 66 bp long segment while cleavage results in $37 \mathrm{bp}$ and 29 bp long fragments. Lane 1: No mutation of $p 53$ gene in well-differentiated tumor; lane 2: Mutation of $p 53$ gene in dedifferentiated tumor; lane 3: DNA marker.

\section{$P C R$ analysis}

PCR was performed using a thermal cycle (PE 9700) with $50 \mathrm{ng}$ of genomic DNA extracted from biopsy samples, 20 pmol of each primer, four deoxynucleotide triphosphates (dNTPs), reaction buffer and $1 \mu \mathrm{L}$ (5 units) of fermentase Taq polymerase in a reaction volume of $100 \mu \mathrm{L}$. The PCR conditions consisted of an initial cycle at $95^{\circ} \mathrm{C}$ for $10 \mathrm{~min}$, at $57^{\circ} \mathrm{C}$ for $1 \mathrm{~min}$, and at $72^{\circ} \mathrm{C}$ for $10 \mathrm{~s}$ followed by 34 cycles at $95^{\circ} \mathrm{C}$ for $1 \mathrm{~min}$, at $57^{\circ} \mathrm{C}$ for $30 \mathrm{~s}$, and at $72^{\circ} \mathrm{C}$ for $10 \mathrm{~s}$. The sequences of primer used are sense: 5'-CAGATGAAGCTCCCAGAA-3' (upstream) and anti-sense: 5'-GTGTAGGAGCTGCTGGTG-3' (downstream). An amplicon of $66 \mathrm{bp}$ was produced, which was cleaved into $29 \mathrm{bp}$ and $37 \mathrm{bp}$ fragments with the enzyme BstU1, if its recognition site (CGCG) was present. The primer amplified a region containing codon 72 in exon 4 of $p 53^{[10,11]}$. Mutation of the $p 53$ gene was only observed in dedifferentiated tumor tissue samples but not in well-differentiated tumor tissue samples (Figure 3).

\section{DISCUSSION}

Mutation or allelic deletion of $p 53$ gene appears to play an important role in the development of human carcinoma ${ }^{[12]}$. It has been established that accumulation of wild type $p 53$ protein results in two pathways: cell cycle arrest and programmed cell death, both of which are involved in tumor suppressor function ${ }^{[13]}$. Therefore, mutation of $p 53$ leads to disruption of these pathways, a selective growth advantage for tumor cells, and loss of function may increase proliferation activity and development of tumor ${ }^{[14]}$.

Liposarcoma arising in extremities or retroperitoneum affects middle-aged and old patients, and tend to follow a relatively indolent clinical course with local recurrences after resection and occasional distant metastasis, mainly to the lungs ${ }^{[1]}$. Dedifferentiated liposarcoma is defined histologically by a transition from well-differentiated liposarcoma to a nonlipogenic sarcoma with variable histological grade ${ }^{[1]}$. The dedifferentiated tumor can resemble any sarcoma, but often mimics a malignant fibrous histiocytoma $(\mathrm{MFH})^{[0]}$.

Dedifferentiated liposarcoma, despite its high-grade histology, has a less aggressive clinical course than other 
types of high grade sarcoma, although the underlying mechanism is unclear ${ }^{[1]}$. Compared to well-differentiated liposarcoma, dedifferentiated liposarcoma has similar genetic changes, ring or giant marker chromosomes, but a worse prognosis ${ }^{[1]}$. Approximately $40 \%$ of dedifferentiated liposarcomas will recur locally, 17\% will metastasize, and $28 \%$ of the patients will ultimately die as a result of tumor ${ }^{[1]}$.

It was reported that dedifferentiated liposarcoma occurs most commonly in retroperitoneum but rarely in other anatomic locations ${ }^{[9]}$. Five cases of dedifferentiated liposarcoma in small bowel mesentery have been described ${ }^{[15]}$. In addition, a case of dedifferentiated liposarcoma has been documented in the sigmoid mesocolon ${ }^{[16]}$. The present tumor, located at intraperitoneum.

Immunohistochemically, dedifferentiated liposarco$\mathrm{ma}$ is usually negative for CD117 and CD34 in dedifferentiated tissue and positive for $\mathrm{S} 100$ protein in well-differentiated tissue. Dedifferentiated liposarcoma needs to be distinguished from other high-grade sarcomas such as MFH because these high-grade sarcomas have a much worse prognosis ${ }^{[17]}$.

We investigated the exon 4 of $p 53$ gene in adipose tissue tumor by PCR observed mutation of $p 53$ gene in dedifferentiated liposarcoma samples. Similarly, Taubert et $a l^{[4]}$ detected mutations of $p 53$ gene in $5 / 32$ of liposarcomas. It was reported that wild type p53 protein can induce cell apoptosis, whereas intracellular accumulation of mutant p53 protein can inhibit cell apoptosis, promote cell transformation and proliferation, resulting in carcinogenesis ${ }^{[5,14]}$.

The patient underwent adjuvant radiation therapy and was asymptomatic during the 15-mo followup period. However, because the recurrence rate of dedifferentiated liposarcoma is very high, it is necessary to follow up carefully for a long term.

\section{REFERENCES}

1 Fletcher CDM, Unni KK, Mertens F. World Health Organization Classification of Tumors. Pathology and Genetics of Tumours of soft tissue and bone. Lyon: IARC Press, 2002; 40-44, 227-232

2 Ichikawa A, Kinoshita T, Watanabe T, Kato H, Nagai H, Tsushita K, Saito H, Hotta T. Mutations of the p53 gene as a prognostic factor in aggressive B-cell lymphoma. $N$ Engl $\mathrm{J}$ Med 1997; 337: 529-534

3 de Anta JM, Jassem E, Rosell R, Martínez-López E, Jassem
J, Monzó M, Sánchez-Hernández JJ, Moreno I, SánchezCéspedes M. TP53 mutational pattern in Spanish and Polish non-small cell lung cancer patients: null mutations are associated with poor prognosis. Oncogene 1997; 15: 2951-2958

4 Taubert H, Meye A, Wurl P. Prognosis is correlated with p53 mutation type for soft tissue sarcoma patients. Cancer Res 1996; 56: 4134-4136

5 Drobnjak M, Latres E, Pollack D, Karpeh M, Dudas M, Woodruff JM, Brennan MF, Cordon-Cardo C. Prognostic implications of p53 nuclear overexpression and high proliferation index of Ki-67 in adult soft-tissue sarcomas. J Natl Cancer Inst 1994; 86: 549-554

6 Kawai A, Noguchi M, Beppu Y, Yokoyama R, Mukai K, Hirohashi S, Inoue H, Fukuma H. Nuclear immunoreaction of p53 protein in soft tissue sarcomas. A possible prognostic factor. Cancer 1994; 73: 2499-2505

7 Diller L, Sexsmith E, Gottlieb A, Li FP, Malkin D. Germline p53 mutations are frequently detected in young children with rhabdomyosarcoma. J Clin Invest 1995; 95: 1606-1611

8 Kindblom LG, Meis-Kindblom JM, Enzinger FM. Variants of liposarcoma. Am J Surg Pathol 1995; 19: 605-606; author reply 606-608

9 Goldblum JR, Weiss SW: Enznger and Weiss's Soft Tissue Tumors. 4th ed. St Louis: Mosby, 2001: 641-693

10 Meltzer SJ, Yin J, Huang Y, McDaniel TK, Newkirk C, Iseri O, Vogelstein B, Resau JH. Reduction to homozygosity involving p53 in esophageal cancers demonstrated by the polymerase chain reaction. Proc Natl Acad Sci USA 1991; 88: 4976-4980

11 Fujita M, Inoue M, Tanizawa O, Iwamoto S, Enomoto T. Alterations of the p53 gene in human primary cervical carcinoma with and without human papillomavirus infection. Cancer Res 1992; 52: 5323-5328

12 Imazeki F, Omata $M$, Nose $H$, Ohto $M$, Isono K. p53 gene mutations in gastric and esophageal cancers. Gastroenterology 1992; 103: 892-896

13 Janus F, Albrechtsen N, Dornreiter I, Wiesmüller L, Grosse F, Deppert W. The dual role model for p53 in maintaining genomic integrity. Cell Mol Life Sci 1999; 55: 12-27

14 Zhou X, Wang XW, Xu L, Hagiwara K, Nagashima M, Wolkowicz R, Zurer I, Rotter V, Harris CC. COOH-terminal domain of p53 modulates p53-mediated transcriptional transactivation, cell growth, and apoptosis. Cancer Res 1999; 59: $843-848$

15 Hasegawa T, Seki K, Hasegawa F, Matsuno Y, Shimodo T, Hirose T, Sano T, Hirohashi S. Dedifferentiated liposarcoma of retroperitoneum and mesentery: varied growth patterns and histological grades--a clinicopathologic study of 32 cases. Hum Pathol 2000; 31: 717-727

16 Winn B, Gao J, Akbari H, Bhattacharya B. Dedifferentiated liposarcoma arising from the sigmoid mesocolon: a case report. World J Gastroenterol 2007; 13: 4147-4148

17 Henricks WH, Chu YC, Goldblum JR, Weiss SW. Dedifferentiated liposarcoma: a clinicopathological analysis of 155 cases with a proposal for an expanded definition of dedifferentiation. Am J Surg Pathol 1997; 21: 271-281

S- Editor Xiao LL L- Editor Wang XL E- Editor Yin DH 